TP Periodica Polytechnica

Mechanical Engineering

60(3), pp. 129-136, 2016

DOI: 10.3311/PPme.8017

Creative Commons Attribution (i)

RESEARCH ARTICLE

\section{Experimental and Numerical Investigation of an Offset Jet Using Tangential Air Distribution System}

\author{
Balázs Both $^{1 *}, Z_{\text {Zoltán Szánthó }}{ }^{1}$
}

Received 02 March 2015; accepted after revision 13 March 2016

\begin{abstract}
In this paper an offset, attached jet is investigated both experimentally and numerically, applying the tangential room air distribution system. The attachment distance of the injected air jet, which influences the ventilation characteristics in the room, is investigated as a function of the inlet Reynolds-number. Results showed that the attachment distance is independent from the inlet Reynolds-number in the range of $\operatorname{Re}_{0}=2 \div 4 * 10^{3}$ with fixed boundary conditions in a room.

In the past decades several researchers have investigated offset jets. However, the tangential room air distribution as a type of comfort ventilation and lower Reynolds numbers have not been considered.

Air velocity magnitude was measured in the injected air jet by a hot-wire anemometer. Three turbulence models were applied for the $3 D$ numerical simulation: standard, $R N G k-\varepsilon$ and SST $k-\omega$ models. In the present work the SST $k-\omega$ model seemed to be the most accurate turbulence model. The numerical results showed a high similarity with the measured data.
\end{abstract}

\section{Keywords}

offset jet, attachment distance, experimental investigation, $C F D$

\footnotetext{
${ }^{1}$ Department of Building Service Engineering and Process Engineering, Faculty of Mechanical Engineering, Budapest University of Technology and Economics, H-1111 Budapest, Bertalan Lajos Street 4-6., Hungary

*Corresponding author, e-mail: both@epget.bme.hu
}

\section{Introduction and theoretical background}

To provide the required comfort parameters in closed areas it is necessary to distribute supply (primary) air efficiently in the occupied zone. The injected primary air jet induces secondary airflows in the ventilated space, thus these primary and secondary airflows constitute an air distribution system [1]. Injected air jets and their distribution in the room play a very important role for each air distribution system. Tangential air distribution system is frequently used in several ventilated spaces. This type of air distribution can provide suitable indoor air comfort in rooms and draught risk can be decreased in the room. With tangential air distribution, a supply air jet is injected into a surface in parallel (mostly this surface is a wall). This injected air jet adheres to the surface, so an offset, attached jet is formed. After this, the air jet flows onto the wall as with a classical wall air jet. The offset, attached and wall air jets play important roles in tangential air distribution systems, so it is necessary to clarify the main difference between offset and wall jets. With wall air jets, the distance between the wall and the air inlet is zero, and the jet attaches to the surface after the air inlet. With offset air jets, the distance between the wall and air inlet is higher than zero, so the air jet attaches to the wall at the attachment point. The distance between the air inlet and the attachment point is the attachment distance $\left(y_{a}\right)$, which is often normalized by the air diffuser's nominal size $s_{0}\left(y_{a} / s_{0}\right.$, see Fig. 1) $[2,3]$. One main advantage of applying offset jets is that the air inlet can be located outside the occupied zone of the ventilated space, near the wall. This means that higher inlet air velocities can be used without draught risk [4].

One of the most important features of offset jets is the attachment point, which separates offset jets from wall jets. This attachment point can influence the airflow characteristics in the room. The attachment process of the air jet is shown on Fig. 1. Supply air is injected from an $s_{0}$ sized slot diffuser with inlet air velocity $v_{0}$. A recirculation zone be seen between the wall and the air inlet. The average pressure in this zone is less than that in the occupied zone $\left(p_{2}<p_{1}\right)$, because there is no air injection from the wall side. After this, the Coanda-effect appears and then the offset air jet attaches to the wall surface and flows onto the wall as a simple wall air jet [5]. 


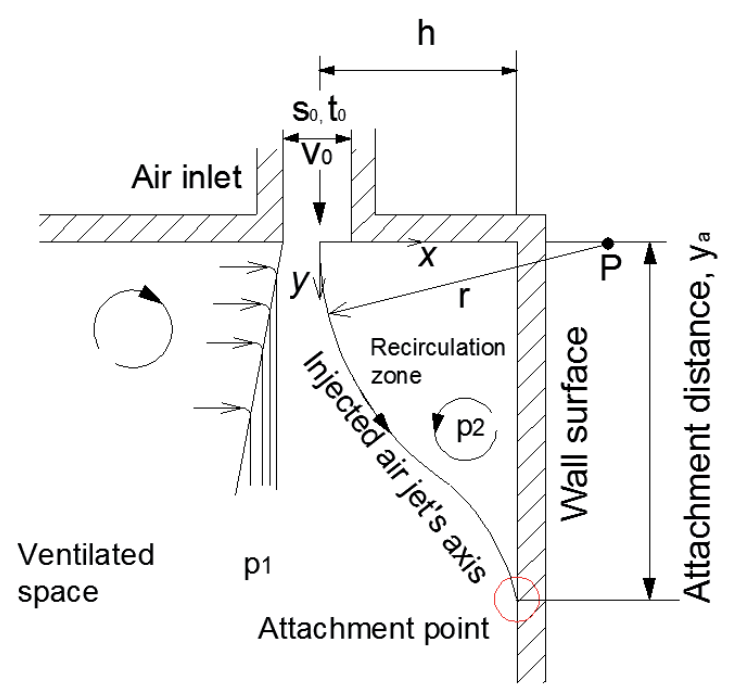

Fig. 1 Scheme of an offset air jet with the most important features

Other important features of offset jets are the horizontal distance between the wall and the air inlet $(h)$, the slot's width $\left(s_{0}\right)$, the slot's length $\left(L_{0}\right.$, which is perpendicular to plane $\left.\mathrm{x}-\mathrm{y}\right)$, air velocity at the air inlet $\left(v_{0}\right)$, air temperature $\left(t_{0}\right)$ and the normalized attachment distance $\left(y_{a} / s_{0}\right)$. Further parameters are the air density $\left(\rho_{0}=f\left(t_{0}\right)\right)$, kinematic viscosity $\left(v_{0}=f\left(t_{0}\right)\right)$ and curvature of the air jet $(r)$. Inlet geometry also plays an important role in the attachment process of the jet by $A R$ (Aspect Ratio) and $O R$ (Offset Ratio) $[6,7]$. AR is the ratio of the air diffuser's length to the diffuser's width:

$$
A R=L_{0} / s_{0}
$$

$O R$ is the ratio of the horizontal distance between the wall and the air inlet to the diffuser's width:

$$
O R=h / s_{0}
$$

The inlet Reynolds-number is:

$$
R e_{0}=\left(v_{0} * s_{0}\right) / v_{0}
$$

One of the earlier publications in this field of research was made in 1934 by Förthmann, who investigated plane and turbulent wall air jets [8]. The following decades brought several offset and wall air jet investigations. Sawyer [9] studied the attachment process of an air jet to a surface both theoretically and experimentally. He found that the attachment point is where the static pressure distribution on the wall has local maximum, or the wall shear stress distribution changes sign. This was also observed by several other researchers $[2,3,5]$. Another way of determining the attachment point was observing the direction of airflow near the wall. In this case the attachment point was where the wall normal air velocity component was zero $[5,6,10]$. Nozaki et al. [6] determined the attachment streamline in the offset jet and the intersection of this streamline and the wall determined the attachment point. T. Magyar [11] investigated offset and wall air jets and air velocity profiles, injected from circle air diffusers. He built the mathematical model of the investigated jets and then performed experimental investigations.

Rajaratnam and Subramanya [3] investigated water jet. They found that there is an analogy between water and air jets, so they used an offset, parallel jet model. They also claimed that at a higher inlet Reynolds-numbers $\left(R e_{0}>10^{4}\right)$ geometry (OR and $A R$ ) has a significant effect on the jet's attachment to the wall. This was also verified by Sawyer [9], Pelfrey and Liburdy [10] and Bourque [12]. After the attachment point, the velocity profiles and decay of maximum air velocity in the wall jets are similar to the classical two-dimensional plane wall jets [10]. Nozaki et al. [6] showed that at higher offset ratios the air diffuser's width has negligible effect on the jet's flow and the attachment process.

At higher offset ratios $(O R=6 \div 70)$ the normalized attachment distance $\left(y_{a} / s_{0}\right)$ is [6]:

$$
y_{a} / s_{0}=1.37 *\left(h / s_{0}\right)+3.0
$$

At smaller offset ratios $(O R<6)$ this normalized attachment distance is [6]:

$$
y_{a} / s_{0}=3.51 *\left(h / s_{0}-1\right)^{0.754}
$$

If $O R<20$, the following formula can be applied to calculate the normalized attachment distance [5]:

$$
y_{a} / s_{0}=2.632 *\left(h / s_{0}\right)^{0.851}
$$

Note that the previous formulas are approximate and semiempirical equations and relate to two-dimensional air jets, where end-walls of the room were not considered. Nozaki et al. also showed that the attachment distance is almost independent from inlet Reynolds-number at the range of $R e_{0}=2 \div 7 * 10^{4}$, if $A R=8$, and $O R=1.6 \div 16$. In case of $A R=1,2$ and 3, respectively $O R=1.6 \div 16$ the effects of inlet Reynolds-number and side wall on the jet's attachment are on the increase, especially if $A R$ is decreasing. This tendency was also verified by Nozaki [7], who found that if $A R>2$, the attachment of the jet is independent from $R e_{0}$, while if $A R<2$, the inlet Reynolds-number has a significant effect on the jet's attachment.

Awbi showed in his book [13] that the jet's attachment only happens if:

$$
h<h_{\text {crit }}=6 * A_{0}^{1 / 2}
$$

where $A_{0}$ is the nominal inlet cross-section. Otherwise, the jet should be considered as a free air jet. In the present work, $A_{0}=L_{0} * s_{0}=1000 * 12=12000 \mathrm{~mm}^{2}$, so the critical distance between the wall and air inlet is $h_{\text {crit }} \approx 657 \mathrm{~mm}$, while $h=260 \mathrm{~mm}$. As $h<h_{\text {crit }}$ in the present case, the injected air jet attaches to the wall and can be considered as an offset, attached jet.

Most investigations in literature were taken in laboratory test facilities. This suggests there was only air inlet without exhaustion and there were no end-walls near the air inlet, so the 
air jet could be considered as two- dimensional. In engineering practice, the tangential room air distribution system is used in smaller rooms, especially in offices. In real circumstances there is always air inlet and exhaustion and the end-walls of the room are near the air diffuser, so the injected air jet is usually considered as three-dimensional. Moureh and Flick [14] and $\mathrm{Yu}$ et al. [15] investigated the airflow in a slot ventilated space, which is similar to the tangential air distribution system, however, these works do not deal with the attachment distance and its determination.

Few investigations used lower inlet Reynolds-numbers under $10^{4}$, which would be very important from the aspect of comfort type ventilation applications. Furthermore, in HVAC (stands for Heating, Ventilation and Air Conditioning) designing, the usual aspect ratio of slot diffusers is higher than $30 \ldots 50$, while the offset ratio is less than $30 \ldots 50$. Most of the earlier investigations were outside in the previously mentioned $R e_{0}, A R$ and $O R$ ranges.

The investigations above were mainly performed using experimental and analytical methods. In case of applying numerical simulation (CFD stands for Computational Fluid Dynamics) partial differential equations, which describe the flow are solved with approximate methods. In fluid mechanics applications and HVAC systems, the finite volume method is commonly used [16]. The mathematical model of closed areas include the continuity equation, equation of movement, energy equation (if thermal processes are investigated), equation contamination of pollutants, etc. [17]. In several engineering applications, the flow is mostly turbulent, so it is needed to model turbulence with different turbulence models. In recent years several investigations have been taken with numerical simulation, in order to investigate air jets. Nasr and Lai [5] applied inhomogeneous numerical meshing in the computational domain. It is important that near rounded faces, slots and complex geometries are needed to apply finer meshing, because the solution changes faster [16]. Nasr and Lai applied the standard $k-\varepsilon$, RNG $k-\varepsilon$ and RS $k-\varepsilon$ turbulence models with power law, second order upwind and QUICK schemes. They found that the standard $k-\varepsilon$ model was more accurate than other turbulence models. Kechiche et al. [18] numerically investigated a turbulent wall jet at lower Reynolds-numbers (between $7.3 * 10^{3}$ and $2.25 * 10^{4}$ ) with $k-\varepsilon$ turbulence model. Moureh and Flick [14] investigated a slot ventilated space with numerical and experimental methods. They used the two-equation $k-\varepsilon$ turbulence and RSM model to predict room ventilation characteristics at $R e_{0}=1.3 * 10^{5}$. Cao et al. [19] numerically investigated ceiling air jets and their effect on the ventilated space in the range of $R e_{0}=1 \div 4 * 10^{3}$. They used the SST $k-\varepsilon$ turbulence model because of the near wall effect with wall function and tetra elements.

The previous investigations were mainly performed in test facilities and did not consider the built-in circumstances and the exact room air distribution system type. Furthermore, most of the investigations applied higher inlet Reynolds-numbers above $10^{4}$, which usually are not used in comfort type ventilation systems because of thermal and draught comfort risk. In most of the HVAC systems the usual inlet Reynolds-numbers are under $10^{4}$.

\section{Investigation aim}

The main aim of this article is to investigate the inlet Reynolds-number's effect on the jet's attachment distance in lower $R e_{0}$ range. Based on a recent literature review, it is clear that inlet Reynolds-number dependence of the attachment distance is possible only if inlet AR is much lower than the usual practical value $(A R<3)$. However, it is needed to investigate the effect of $R e_{0}$ on the attachment distance in real circumstances, which were not considered in previous researches:

- Tangential room air distribution system with vertical air supply and vertical air exhaust.

- End-walls of the ventilated room are near the air inlet.

- Much lower $R e_{0}$ range that was applied in most of the previous researches. In comfort type HVAC systems the usual inlet $R e_{0}$ range goes from 2,000 to 4,000 in tangential room air distribution systems.

Each scientific problem can be solved with three different methods: with analytical, experimental and numerical methods. In this paper, the attachment distance of the air jet was investigated using experimental and numerical methods.

\section{Experimental method}

Measurements were performed in a full-scale model room of a typical cellular office, with $3 \times 3 \mathrm{~m}$ basic area and $2.8 \mathrm{~m}$ interior height at Budapest University of Technology and Economics, Department of Building Service and Process Engineering, Ventilation Laboratory. Ventilation design criteria of cellular offices are in standard CR 1752 [20]. In the test room, which was thermally insulated against external heat gains; tangential room air distribution system was used. Location of the air inlet can be seen in Fig. 2.

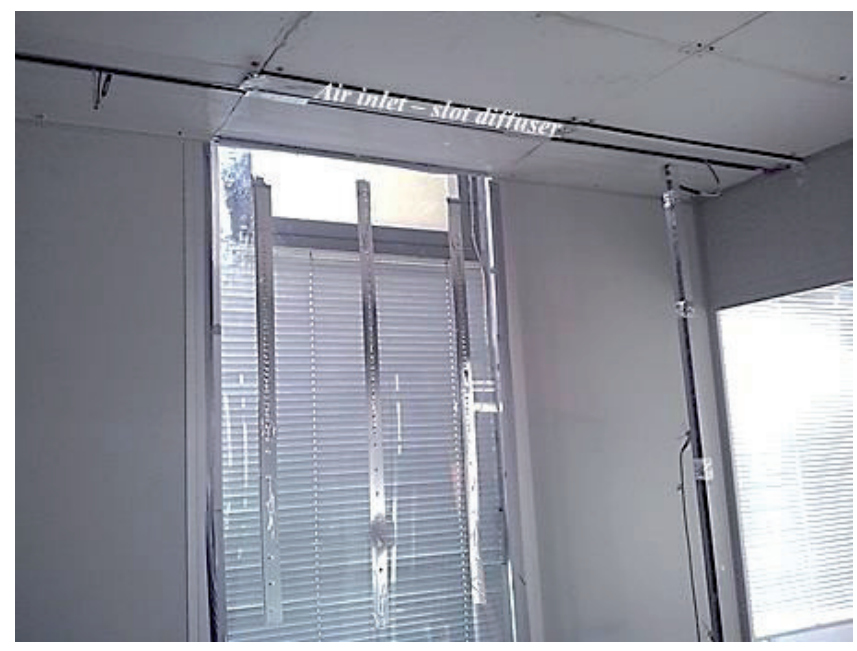

Fig. 2 Location of the air inlet in the test room 
Boundary conditions of the experimental investigations were:

- Steady and turbulent airflow.

- Isothermal air injection from 1-line slot diffuser with vertical air supply and vertical air exhaust.

- Basic area of the test room was $9 \mathrm{~m}^{2}$ with interior height $2.8 \mathrm{~m}$. This arrangement was a typical single (cellular) office room according to standard CR 1752 [20].

- The inlet geometry was: $L_{0}=1000 \mathrm{~mm}, s_{0}=12 \mathrm{~mm}$, $h=260 \mathrm{~mm}$, so $A R=83.3$ and $O R=21.7$.

- At the air inlet $v_{0}=2 \div 6 \mathrm{~m} / \mathrm{s}$, so the inlet Reynoldsnumber was $R e_{0}=2 \div 4 * 10^{3}$.

Air velocity magnitude was measured in the air jet with hotwire anemometer (Fig. 3), according to the relevant standards [21, 22, 23] in plane x-y (Fig. 1).

There was $12 \mathrm{~mm}$ distance between the measurement points in $\mathrm{x}$-direction and $100 \mathrm{~mm}$ in y direction. The size of the whole measurement plane was $600 \mathrm{~mm}$ in $\mathrm{x}$-direction and $1,500 \mathrm{~mm}$ in y-direction in the injected air jet. This meant 750 measurement points in the measurement plane. The safety distance of the probe was $10 \mathrm{~mm}$ from the wall, considering the probe's protection. Ambient air temperature was measured by $\mathrm{NiCr}-\mathrm{Ni}$ based thermometer due to standard [23].

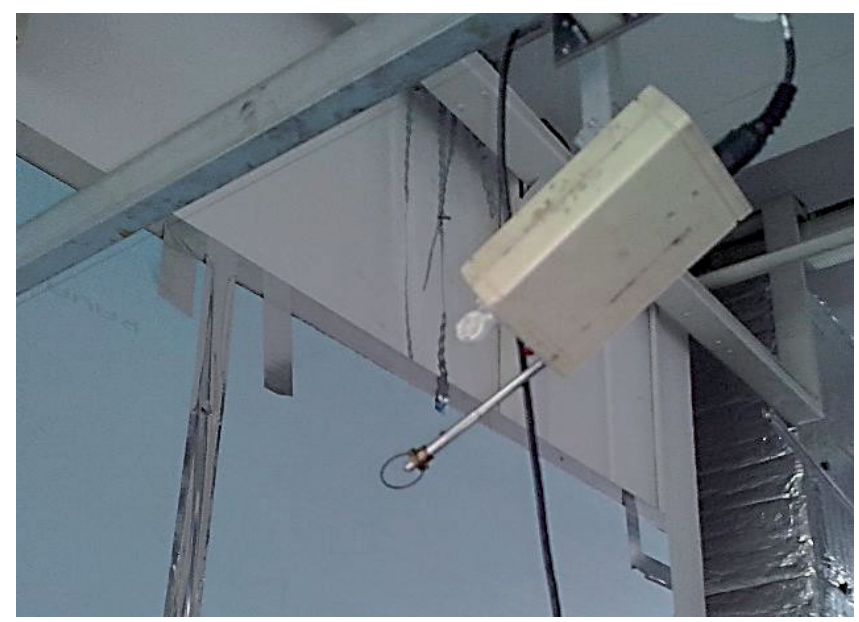

Fig. 3 Hot-wire anemometer probe

Figure 4 shows the sketch of the ventilation system. The hot-wire anemometer was connected to a computer (PC), which collected the measured data. A CRAC device (stands for Computer Room Air Conditioning) handled the circulated air in the ventilation system. The airflow was controlled and measured by an orifice plate with a controlling valve. All of the measured data were collected in a text-file and then transported and evaluated with statistical methods.

Figure 5 contains the locations of maximum air velocity magnitude in the jet. On the horizontal axis is the location of maximum air velocity magnitude $\left(x_{v \max }\right)$ measured from the wall. On the vertical axis is the distance from air inlet, normalized by the nominal size of the slot diffuser. The curvature of the offset jet can be seen clearly between the air inlet and the wall. The approximate attachment point was $y_{a} / s_{0} \approx 120$ at $x_{v \max }=10 \mathrm{~mm}$ (considering the distance between the probe's head and the wall). Note that this $x_{\mathrm{vmax}}=10$ was not on the wall, because of the safety distance and also air velocity on the wall is zero $\left(v_{\text {wall }}=0\right)$.

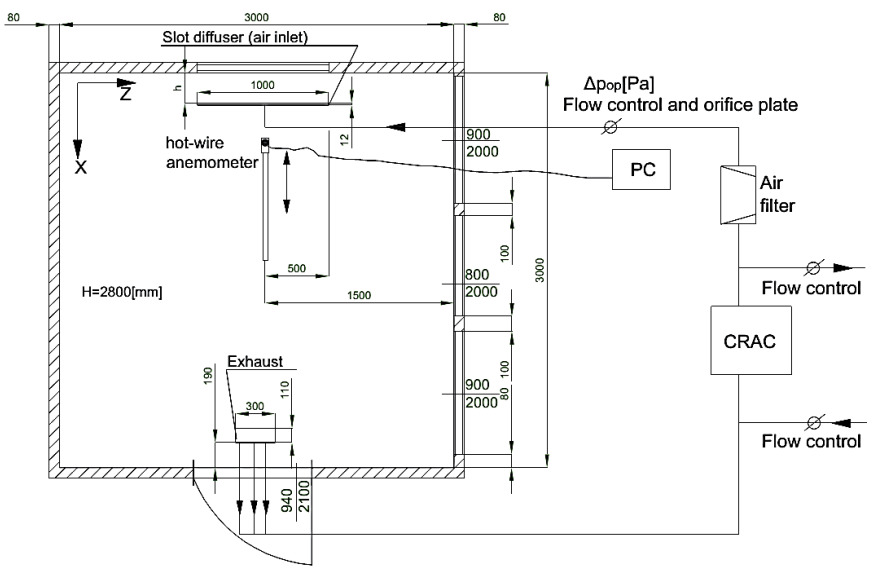

Fig. 4 Sketch of the ventilation system

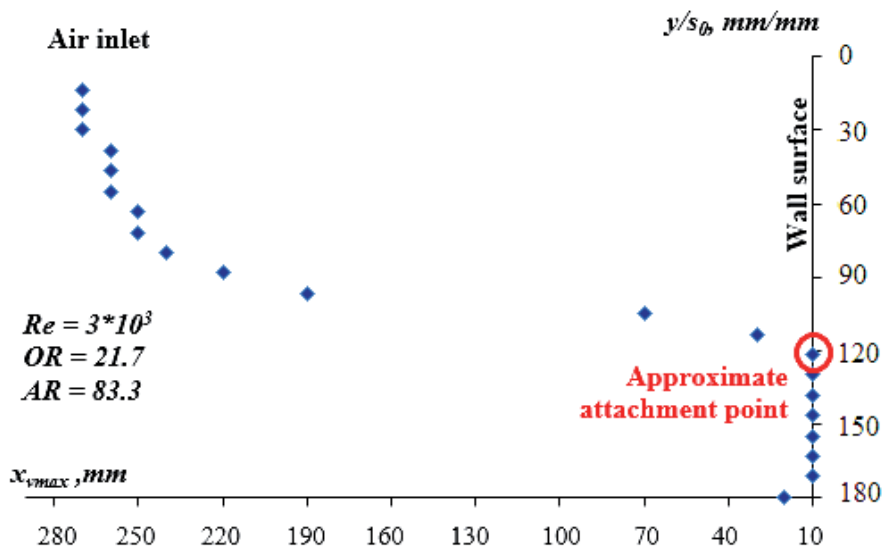

Fig. 5 Location of maximum (or axis) air velocity magnitude in the jet

The approximate attachment distance as a function of inlet Reynolds-number is plotted on Fig. 6.

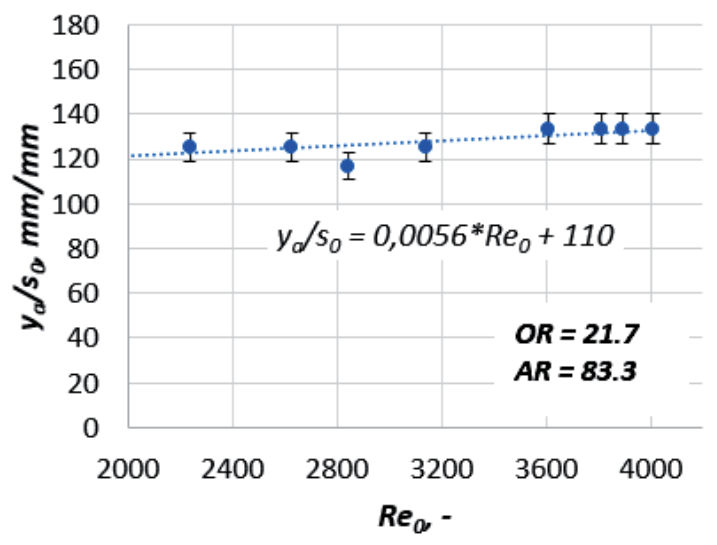

Fig. 6 Approximate attachment distance as a function of inlet Reynolds-number 
It is clear that in the range of $R e_{0}=2 \div 4 * 10^{3}$, the approximate attachment distance $\left(y_{a} / s_{0}\right)$ changes slightly as a function of inlet Reynolds-number in the investigated room. General regression and Abbe tests [24] were applied in order to investigate the approximate attachment distance's dependence on inlet Reynolds-number. Normal distribution of the measured data was assumed and the probability levels were 90, 95 and $99 \%$ during the tests. In the present work, the fitted regression curve was linear:

$$
y=\alpha+\beta * x
$$

The null hypothesis of the regression test was that rise of the regression curve is zero:

$$
\mathrm{H}_{0}: \beta=0
$$

While the anti-hypothesis was:

$$
\mathrm{H}_{1}: \beta \neq 0
$$

The null hypothesis of the Abbe test was that the expected value of the attachment distance is constant. Calculated values of the test statistic were compared to the critical values at the three probability levels and the null hypothesis could be accepted in the two tests. This meant that the rise of the regression curve was zero and the expected value of the approximate attachment distance was constant. In other words, the approximate attachment distance was found to be independent from the inlet Reynolds-number in the range of $R e_{0}=2 \div 4 * 10^{3}$. This result agrees with previous literature results, however, there were applied higher inlet Reynolds-numbers, and investigations were performed on test facilities, not in a room.

As the approximate attachment distance depends on several parameters, it could be assumed that it had a normal distribution [24]. The approximate attachment distance has an expected value in the investigated $R e_{0}$ range, which is $y_{a} / s_{0}=128$. Confidence intervals of this expected value at different significance levels are:

$$
\begin{aligned}
& P\left(125<y_{a} / s_{0} \leq 131\right)=0.90 \\
& P\left(124<y_{a} / s_{0} \leq 132\right)=0.95 \\
& P\left(123<y_{a} / s_{0} \leq 133\right)=0.99
\end{aligned}
$$

Note that this approximate attachment distance was determined with an air velocity magnitude measurement in the injected air jet's axis. Some researchers suggested that the attachment distance can be determined directly on the wall by investigating the wall shear stress distribution. The attachment point is where the wall shear stress changes sign. In the present work, the wall shear stress distribution was determined by numerical simulation.

\section{1 Measurement uncertainty}

Each measured quantity is loaded with uncertainty. In order to provide a precise and correct evaluation of measured data it is necessary to determine these uncertainties [24]. Air velocity magnitude was a directly measured value and the absolute uncertainty of the measured air velocity magnitude was given by the manufacturer of the hot-wire anemometer: $0.03 \mathrm{~m} / \mathrm{s}$. The minimum relative measurement uncertainty of maximum velocity magnitude in the jet was $0.6 \%$, while the maximum uncertainty was $3.1 \%$, which was under $5 \%$ [23].

The inlet Reynolds-number was a calculated value, which used the measured air velocity and temperature. The minimum relative measurement uncertainty of the inlet Reynolds-number was $0.6 \%$, while the maximum was $1.5 \%$, which was also under $5 \%$ [23].

\section{Numerical method}

The numerical simulation was made with Ansys Fluent 12.1 CFD software, which used a $3 \mathrm{D}$ geometry model. The inlet Reynolds-number range was $\operatorname{Re}_{0}=2 \div 4 * 10^{3}$, while the initial turbulence intensity at air inlet was $7 \%$, according to previous measurements. Hexahedron elements were used in the whole domain by sweep method. The geometry was the same as the investigated model room. According to the simple room geometry, a symmetric model was used (Fig. 7).

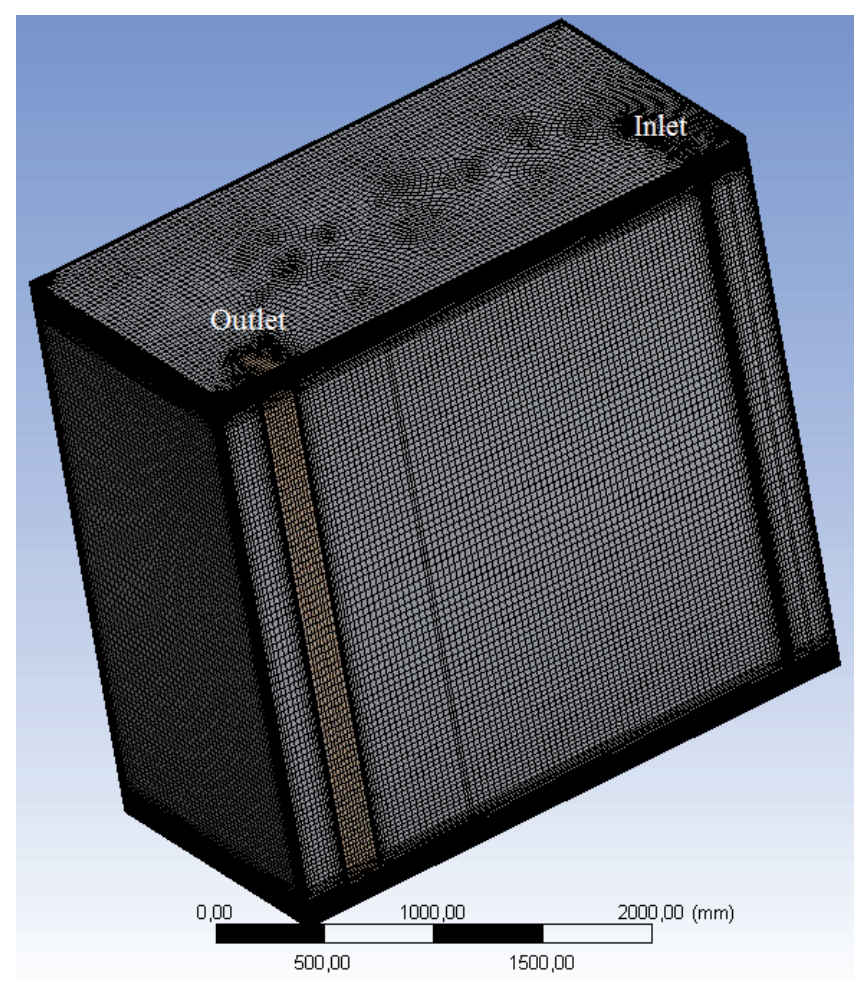

Fig. 7 The symmetric 3D geometry model

Wall inflation was applied near the wall surface, applying smooth transition with transition ratio $0.5,6$ layers and growth rate 1.5. Three different turbulence models were applied: standard and RNG $k-\varepsilon$ models with wall function and SST $k-\omega$ 
model. For the $k-\omega$ model it is necessary to have the cells closer to the surface. The first cell should in the viscous layer, so the normalized distance from the wall surface should be less, than $y^{+}=5$. All of the turbulence models used coupled numerical scheme, respectively QUICK, power law and second order upwind discretization. The air was set to incompressible and ideal gas during the simulations.

It is very important to investigate grid independence on an integral value because of the calculation time of the numerical model. Figure 8 shows the maximum wall static pressure, which is an overpressure, (as a surface integral value) as a function of the number of cells.

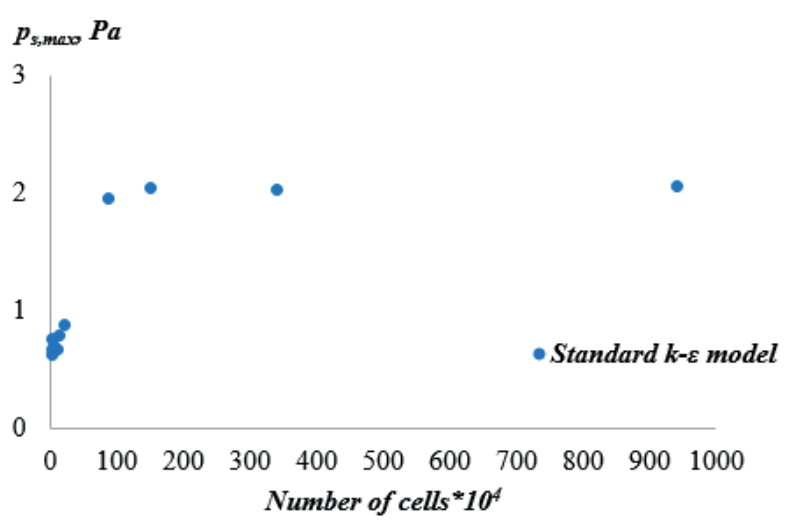

Fig. 8 Grid independence investigation

It can be seen that under $100 * 10^{4}=10^{6}$ cells, this integral value changes significantly, however, over $10^{6}$ cells this value is almost independent from the number of cells (grid resolution). In the present case, this meant 1151236 cells with $220 \mathrm{~mm}$ max hexahedron element size. The numerical solver was pressurebased with steady-flow and 5,000 iteration steps.

Air velocity profiles in the injected air jet are plotted and compared with measured values on Fig. 9. It is obvious that the SST $k-\omega$ model approximates the measured profile well. Based on the numerically determined velocity profiles, the maximum values of air velocity magnitudes can be extracted.

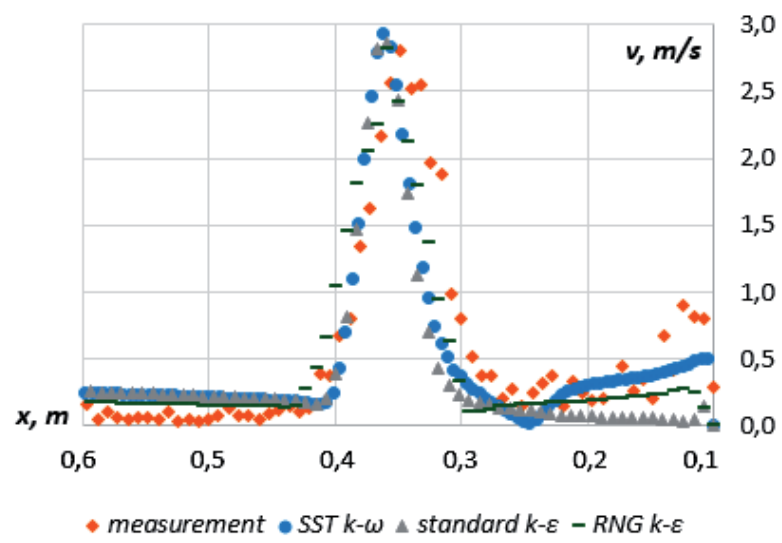

Fig. 9 Air velocity profiles in the air jet near the air inlet at $R e_{0}=3 * 10^{3}$, $O R=21.7, A R=83.3$
Using the locations of the maximum velocity magnitudes, similarly like in the measurement method, attachment point of the air jet could be determined. Figure 10 shows the numerically determined approximate attachment distances compared to the measurement results.

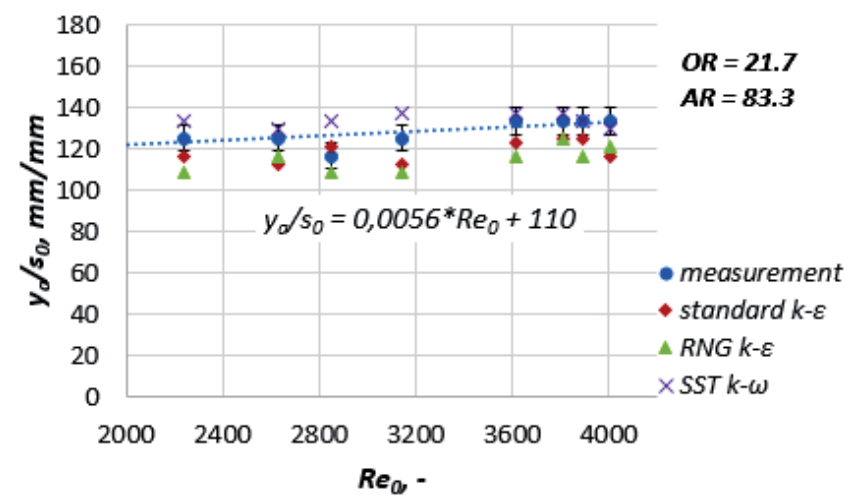

Fig. 10 Numerically and experimentally determined approximate attachment distances

The numerically determined approximate attachment distances fit well to the measured data. The SST $k-\omega$ turbulence model showed the best fit to the measured data.

Wall shear stress distribution at different inlet Reynoldsnumbers (in vertical direction) along the wall surface can be seen on Fig. 11.

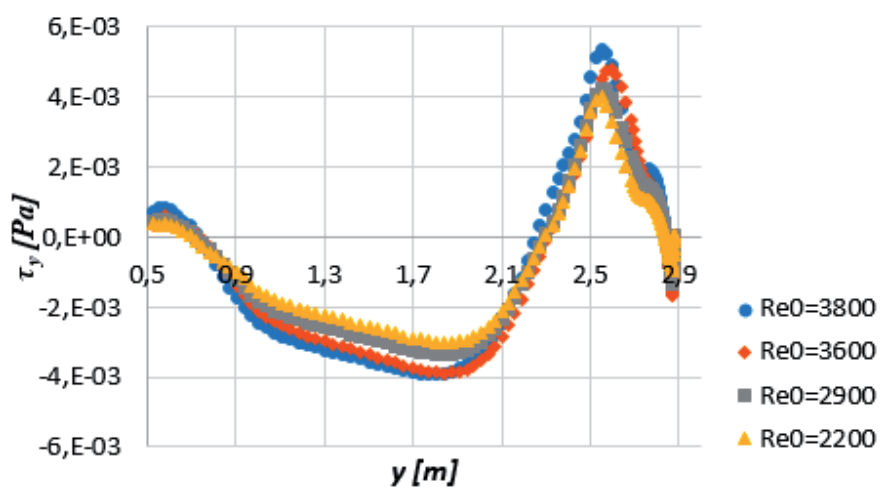

Fig. 11 Numerically calculated y-wall shear stress distributions along the wall at some inlet Reynolds-numbers, in the range of $R e_{0}=2 \div 4 * 10^{3}$, SST $k-\omega$ model

In Figure 11 it is clear that the y-wall shear stress distribution is almost the same at some inlet Reynolds-numbers in the investigated range. The attachment point of the injected air jet on the wall is where the wall shear stress changes sign. This point is approximately $y=2.2 \mathrm{~m}$ in the CFD global coordinate system, which is $0.6 \mathrm{~m}$ from the air inlet (total interior height of the room was $2.8 \mathrm{~m}$ ). Based on the numerically calculated wall shear stress distributions, the attachment distances directly on the wall are shown in Fig. 12. 


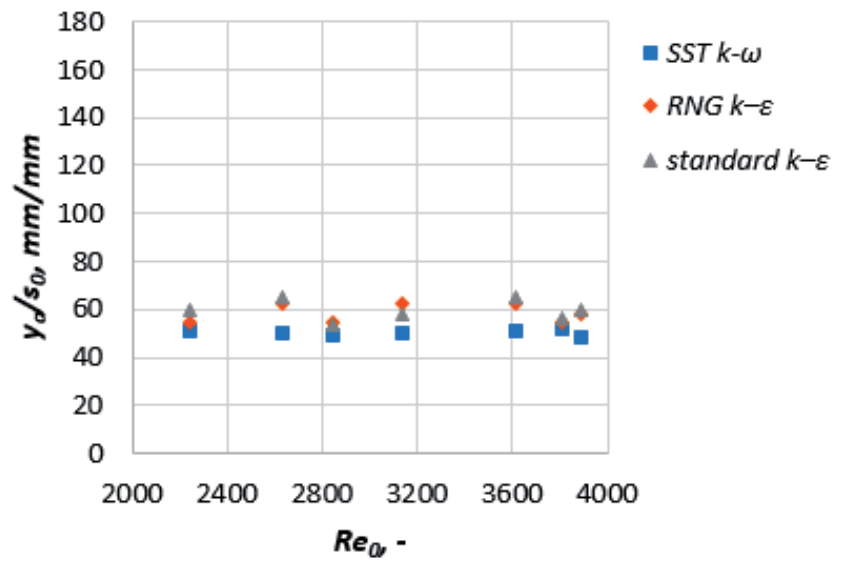

Fig. 12 Attachment distances on the wall, based on the numerically calculated wall shear stress distribution, $O R=21.7, A R=83.3$

It can be seen that the attachment distance, directly on the wall is also independent from the inlet Reynolds-number and it is smaller than the approximate attachment distance near the wall. The main reason for this smaller value is that the approximate attachment distance was determined in the air jet's axis, while the attachment distance on the wall is determined from the jet's margin. The jet's margin always attaches to the wall sooner than the jet's axis.

\section{Conclusions and summary}

In the present article a wall bounded offset jet and its attachment were investigated using experimental methods and numerical methods. Air velocity magnitude was measured in the air jet with a hot-wire anemometer in a cellular office fullscale model room. Based on maximum (axial) air velocities, the axis of the injected air jet and the approximate attachment distance could be determined. Experimental results showed that the approximate attachment distance is independent from inlet Reynolds- number at three probability levels: 90, 95 and $99 \%$. The investigated inlet Reynolds-number range went from $2 * 10^{3}$ to $4 * 10^{3}$ with a constant inlet offset and aspect ratio. The results consider the real circumstances of tangential room air distribution systems, like end-walls near the air inlet, vertical air inlet and exhaust in a room and lower inlet Reynoldsnumbers, which are more frequent in comfort type HVAC systems. The expected values of the approximate attachment distances were estimated with confidence intervals.

A numerical model was created with symmetric 3D geometry in order to complete the measurement results. Boundary conditions of the numerical simulation were based on previous measurement results of the present research. Three turbulence models were used: standard and RNG $k-\varepsilon$ models and SST $k-\omega$ model. Hexahedron elements were used for meshing with wall inflation, considering that the wall y-plus values should be less than 5. Grid-independence investigation was made and 1,151,236 cells with $220 \mathrm{~mm}$ max hexahedron element size seemed to be enough. Steady-state simulation was run with 5,000 iteration steps. Air velocity profiles were determined numerically and then investigating its maximum values the approximate attachment distance could be determined, similarly to the measurements. Numerical results showed good similarity to the measurement results, especially the SST $k-\omega$ turbulence model. Finally, the wall shear stress distribution was determined numerically and then the attachment distance was where this distribution changed sign. This numerically determined attachment distance from wall shear stress distribution was also independent from inlet Reynolds-number. However, it was smaller than the approximate attachment distance. The main reason for this smaller value was that the approximate attachment distance was determined in the air jet's axis, while the attachment distance on the wall was determined from the jet's margin. The jet's margin always attaches to the wall sooner than the jet's axis.

These results can help to describe and design the occupied zones of slot ventilated spaces in a more accurate way [25].

\section{Acknowledgement}

The authors would like to thank the Richter Gedeon Talentum Foundation for supporting this research project. Furthermore special thanks to Róbert Goda $\mathrm{PhD}$, assistant professor at BUTE for supervising this project.

\section{References}

[1] Magyar, T. "Helyiségek légvezetési rendszerei és a hőérzeti méretezés kapcsolata." In: Symposium, Budapest, Hungary, May 1993, pp. 1-43. (in Hungarian)

[2] Rathore, S. K., Das, M. K. "Comparison of two low- Reynolds number turbulence models for fluid flow study of wall bounded jets." International Journal of Heat and Mass Transfer. 61, pp. 365-380. 2013. DOI: 10.1016/j.ijheatmasstransfer.2013.01.062

[3] Rajaratnam, N., Subramanya, N. "Plane turbulent reattached wall jets." Proceedings of the ASCE, Journal of the Hydraulic Division. 94, pp. 95-112. 1968.

[4] Pénzes, Gy. "Sugárszellőzés alkalmazási lehetőségei." In: ÉTI Évkönyv 1977, pp. 330-339. (in Hungarian)

[5] Nasr, A., Lai, J. C. S. "A turbulent plane offset jet with small offset ratio." Experiments in Fluids. 24, pp. 47-57. 1998.

DOI: $10.1007 / \mathrm{s} 003480050149$

[6] Nozaki, T., Hatta, K., Nakashima, M., Matsumura, H. "Attachment flow issuing from a finite width nozzle." Bulletin of the JSME. 22, pp. 340347. 1979.

[7] Nozaki, T. "Attachment flow issuing from a finite width nozzle (report 4: Effects of aspect ratio of the nozzle)." Bulletin of the JSME. 26(221), pp. 1884-1890. 1983.

[8] Förthmann, E. "Über turbulente Strahlausbreitung." (Turbulent jet expansion.) Ingenieur-Archiv. 5(1), pp. 42-54. 1934. (in German) DOI: $10.1007 / \mathrm{BF} 02086177$

[9] Sawyer, R. A. "The flow due to a two-dimensional jet issuing parallel to a flat plate." Journal of Fluid Mechanics. 9(04), pp. 543-559. 1960. DOI: $10.1017 / \mathrm{S} 0022112060001304$

[10] Pelfrey J. R. R., Liburdy, J. A. "Mean flow characteristics of a turbulent offset jet." Journal of Fluids Engineering. 108(1), pp. 82-88. 1986. DOI: $10.1115 / 1.3242548$ 
[11] Magyar, T. "Egy irányban határolt izotermikus levegősugár viselkedése zárt terekben." $\mathrm{PhD}$ thesis, Budapest University of Technology and Economics, 1979. (in Hungarian)

[12] Bourque, C., Newman, B. G. "Reattachment of a two-dimensional jet to an adjacent flat plate." Aeronautical Quarterly. 11(3), pp. 201-232. 1960.

[13] Awbi, H. "Ventilation of Buildings." Second Edition, Spon Press, London and New York, 2005, pp. 163-165, pp. 348-444.

[14] Moureh, J, Flick, D. "Airflow characteristics within a slot-ventilated enclosure." International Journal of Heat and Fluid Flow. 26(1), pp. 12-24. 2005. DOI: 10.1016/j.ijheatfluidflow.2004.05.018

[15] Yu, H., Liao, C. M., Liang, H. M., Chiang, K. C. "Scale model study of airflow performance in a ceiling slot-ventilated enclosure: Nonisothermal condition." Building and Environment. 42(3), pp. 1142-1150. 2007. DOI: 10.1016/j.buildenv.2005.12.004

[16] Kristóf, G. "Áramlások numerikus modellezése." Electronic book, BME 2014. (in Hungarian) URL: http://www.ara.bme.hu/ kristof/CFDjegyzet/

[17] Magyar, T., Goda, R. "Laboratory modelling of tangential air supply system." Periodica Polytechnica Mechanical Engineering. 44(2), pp. $207-$ 215. 2000. URL: http://www.pp.bme.hu/me/article/view/1442

[18] Kechiche, J., Mhiri, H., Le Palec, G., Bournot, P. "Numerical study of the inlet conditions on a turbulent plane two dimensional wall jet." Energy Conversion and Management. 45(18-19), pp. 2931-2949. 2004.

DOI: 10.1016/j.enconman.2003.12.021
[19] Cao, G., Ruponen, M., Paavilainen, R., Kurnitski, J. "Modelling and simulation of the near-wall velocity of a turbulent ceiling attached plane jet after its impingement with the corner." Building and Environment. 46(2), pp. 489-500. 2011. DOI: 10.1016/j.buildenv.2010.08.012

[20] CR 1752:2000. Ventilation for buildings. Design criteria for the indoor environment. 2000.

[21] EN ISO 5167-1:2003. Measurement of fluid flow by means of pressure differential devices inserted in circular cross-section conduits running full -Part 1: General principles and requirements. 2003.

[22] EN 24006:2002. Measurement of fluid flow in closed conduits. 2002.

[23] EN ISO 7726:2003. Ergonomics of the thermal environment - Instruments for measuring physical quantities. 2003.

[24] Kemény, S., Deák, A. "Kisérletek tervezése és értékelése." Műszaki Könyvkiadó, Budapest, 2000. (in Hungarian)

[25] Goda, R. "Turbulence intensity and air velocity characteristics in a slot ventilated space." Periodica Polytechnica Mechanical Engineering 58(1), pp. 1-6. 2014. DOI: 10.3311/PPme.7154 